\title{
PENGEMBANGAN SISTEM INFORMASI AKADEMIK BERBASIS WEB DI SMK BAKTI IDHATA JAKARTA
}

\author{
Muhammad Nur Afandy ${ }^{1}$, Widodo², Bambang Prasetya Adhi ${ }^{3}$ \\ ${ }^{1}$ Mahasiswa Prodi Pendidikan Informatika, Teknik Elektro, FT - UNJ \\ ${ }^{2,3}$ Dosen Prodi Pendidikan Informatika, Teknik Elektro, FT - UNJ \\ ${ }^{1}$ muhammadnurafandy@gmail.com, ${ }^{2}$ widodo@unj.ac.id, ${ }^{3}$ bambangpadhi@unj.ac.id
}

\begin{abstract}
Abstrak
Penelitian ini bertujuan mengembangkan sistem informasi penilaian dengan basis web, untuk mengembangkan sistem sebelumnya di SMK Bakti Idhata Jakarta yang menerapkan sistem pengolahan penilaian berbasis aplikasi spreadsheet yang masih ada kekurangan dalam pelaksanaannya, yaitu belum dipakai secara sistematis, belum fleksibel, dan belum terbuka dalam hal penilaian. Pengembangan sistem ini menggunakan metode pengembangan Agile yaitu model Scrum. Proses dalam Scrum menggunakan tiga fase, yaitu fase pre-game, merancang segala kebutuhan dalam proses pengembangan. Fase game, melakukan proses pengembangan yang dibagi dalam dua sprint secara iterasi sekaligus incremental. Terakhir fase post-game, saat sistem siap digunakan. Berdasarkan hasil pengujian fungsional oleh pihak sekolah, yaitu terdiri atas empat pengguna (administrator, guru mata pelajaran, wali kelas, dan siswa), sistem ini berjalan dengan baik dalam mengolah penilaian sesuai kurikulum 2013, menghasilkan laporan penilaian, dan mendukung keputusan kenaikan kelas sederhana.
\end{abstract}

Kata kunci : sistem informasi akademik, sistem berbasis web, kurikulum 2013, metode pengembangan agile, scrum.

\section{Pendahuluan}

\subsection{Latar Belakang}

Evaluasi pembelajaran sebagai suatu kegiatan mengumpulkan data dan informasi mengenai kemampuan belajar siswa, untuk menilai pembelajaran yang telah berjalan, dan juga sebagai suatu alat untuk menentukan tujuan pendidikan dan proses pembelajaran dalam mengembangkan ilmu pengetahuan telah berlangsung dengan baik. Evaluasi bertujuan untuk mengetahui tingkat pencapaian siswa dalam suatu proses pembelajaran. Fungsi evaluasi untuk membantu proses, kemajuan dan perkembangan hasil belajar peserta didik secara berkesinambungan, dan sekaligus dapat mengetahui kemampuan dan kelemahan siswa pada bidang pelajaran tertentu. (Mahirah, 2017).

Penilaian pendidikan merupakan proses pengumpulan dan pengolahan informasi untuk mengukur pencapaian hasil belajar peserta didik mencakup: penilaian kinerja, penilaian diri, penilaian berbasis portofolio, penilaian harian, penilaian tengah semester, penilaian akhir semester, ujian tingkat kompetensi, ujian mutu tingkat kompetensi, ujian nasional, ujian sekolah berstandar nasional, dan ujian sekolah/madrasah (Kemendikbud, 2017).

Berdasarkan Permendikbud Nomor 23 Tahun 2016 tentang Standar Penilaian Pendidikan, dalam setiap aktivitas penilaian pendidikan tidak dapat dilepaskan dari prinsip-prinsip penilaian yaitu: sahih, obyektif, adil, terpadu, terbuka, menyeluruh dan berkesinambungan, sistematis, mengacu kriteria, akuntabel, dan andal.

Sekolah Menengah Kejuruan Bakti Idhata Jakarta memiliki penjurusan Rekayasa Perangkat Lunak, Teknik Komputer Jaringan, dan Multimedia. Pada saat ini menerapkan penilaian berdasarkan kurikulum 2013 yang mencakup aspek penilaian pengetahuan, sikap, dan keterampilan. Sekolah ini menerapkan sistem pengolahan penilaian terkomputerisasi berbasis aplikasi spreadsheet yaitu Microsoft Excel. Aplikasi ini hanya dipakai dalam proses pengolahan nilai dan pencetakan rapor siswa.

Sistem informasi berbasis aplikasi spreadsheet ini meskipun terkomputerisasi, masih terdapat kekurangan dalam pelaksanaannya. Format penilaian setiap guru mata pelajaran berbeda-beda sehingga saat pemasukan nilai ke dalam aplikasi, harus disesuaikan terlebih dahulu. Guru mata pelajaran juga memiliki bobot penilaian yang berbeda-beda antara nilai tugas, ulangan harian, ulangan tengah semester, maupun ulangan akhir semester. Sehingga saat memasukkan penilaian ke dalam sistem harus disesuaikan kembali. Dibutuhkan sebuah sistem yang tidak kaku dalam menerima penilaian dari guru mata pelajaran dan tetap mengikuti aturan penilaian kurikulum 2013. Maka penulis mengusulkan dibuatkan sistem informasi dengan basis web, karena selain fleksibel dalam pengolahan nilai, web juga fleksibel dalam hal akses yang tidak dibatasi platform perangkat. 
Penulis menemukan kekurangan pada sistem informasi sebelumnya yang

berbasis aplikasi ini belum dipakai secara sistematis karena akses pengisian nilai hanya pada pembuat aplikasi dan wali kelas. Akses yang terbatas ini mengakibatkan proses pengisian data nilai masih manual dengan menyalin berkas data nilai yang diserahkan oleh para guru mata pelajaran.

Aplikasi ini juga belum fleksibel karena pembuat aplikasi harus mendistribusikan aplikasinya kepada wali kelas. Apabila ada perubahan baik struktur data penilaian maupun mata pelajaran, maka pembuat aplikasi harus mengubah programnya. Hal ini akan menyebabkan tidak adanya pemeliharaan jangka panjang akibat aplikasi harus selalu diubah tiap tahun dan didistribusikan kembali. Sehingga dibutuhkan sistem informasi yang dapat menjangkau pihak sekolah lebih luas dan dapat diakses tanpa terikat sebuah platform aplikasi dalam hal ini aplikasi spreadsheet.

Dalam hal keterbukaan penilaian karena akses hanya sebatas pihak sekolah, siswa melihat nilai setelah mendapat rapor. Dalam kasus nilai harian, siswa mengetahui perkembangan penilaian apabila guru mata pelajaran bersangkutan memberitahukannya. Dibutuhkan sistem yang mengakomodasi siswa agar bisa memantau perkembangan penilaian yang objektif dan memudahkan guru mata pelajaran dalam mengadakan remedial serta dapat membantu mengevaluasi aspek mengajarnya.

Selain itu, data hanya digunakan sebatas menilai siswa, sistem belum bisa mengolah data dalam mendukung keputusan kenaikan kelas jika ada kasus siswa yang diragukan naik kelas. Jika data penilaian siswa digunakan dalam pengambilan keputusan ini, maka pihak sekolah tidak perlu mengecek setiap hasil penilaian siswa dan akan membantu dalam rapat kenaikan kelas.

Berdasarkan masalah-masalah yang telah dikemukakan, penulis mengajukan penelitian dengan judul "Pengembangan Sistem Informasi Akademik Berbasis Web di SMK Bakti Idhata Jakarta". Sistem berbasis web ini diharapkan dapat meningkatkan sistem sebelumnya dengan pemakaian yang mudah diakses, fleksibel, dan obyektif sehingga sesuai dengan prinsip penilaian pendidikan berdasarkan Permendikbud Nomor 23 Tahun 2016 tentang Standar Penilaian Pendidikan yaitu fleksibel, sistematis dan terbuka. Data yang terhimpun juga akan digunakan dalam proses evaluasi pembelajaran dan diolah dalam mendukung pengambilan keputusan dari pihak sekolah terkait kenaikan kelas.

\subsection{Rumusan Masalah}

Berdasarkan latar belakang, identifikasi, dan batasan masalah, maka dapat dirumuskan permasalahan, yaitu bagaimana mengembangkan Sistem Informasi Akademik berbasis web di SMK Bakti Idhata Jakarta.

\subsection{Tujuan Penelitian}

Berdasarkan rumusan masalah di atas, tujuan yang ingin dicapai dari penelitian ini adalah menghasilkan Sistem Informasi Akademik berbasis web di SMK Bakti Idhata Jakarta

\section{Dasar Teori}

\subsection{Definisi Sistem}

Secara sederhana sistem dapat diartikan sebagai suatu kumpulan atau himpunan dari unsur, komponen, atau variabel yang terorganisasi, saling berinteraksi, saling tergantung satu sama lain dan terpadu. Terdapat dua pendekatan dalam mendefinisikan sistem, yaitu pendekatan prosedur dan pendekatan elemen atau komponen. Pada pendekatan prosedur, definisi sistem adalah suatu jaringan kerja prosedur-prosedur yang saling berhubungan, berkumpul bersama-sama untuk melakukan suatu kegiatan atau untuk menyelesaikan suatu sasaran tertentu. Sedangkan pada pendekatan elemen atau komponen menyatakan bahwa definisi sistem adalah kumpulan elemen yang berinteraksi untuk mencapai tujuan tertentu. (Tata, 2012:2-3).

Prajudi Atmosudirdjo dalam bukunya Tata Sutabri (2012:7), menyatakan bahwa suatu sistem terdiri dari atas objek-objek atau unsur-unsur atau komponen-komponen yang berkaitan dan berhubungan satu sama lainnya sedemikian rupa sehingga unsur-unsur tersebut merupakan suatu kesatuan pemrosesan atau pengolahan yang tertentu. Sedangkan menurut Ludwig von Bertalanfly, sistem merupakan seperangkat unsur-unsur yang terikat dalam suatu antar relasi di antara unsur-unsur tersebut dan dengan lingkungannya. Unsur-unsur yang mewakili suatu sistem secara umum adalah masukan (input), pengolahan (processing), dan keluaran (output). Komponen atau elemen dalam suatu sistem tidak dapat berdiri lepas sendiri-sendiri, komponen ini saling berinteraksi atau saling berhubungan membentuk satu kesatuan sehingga tujuan atau sasaran sistem dapat dicapai. (Yakub dan Hisbanarto, 2014).

Dari beberapa definisi sistem di atas, dapat disimpulkan bahwa sistem adalah kumpulan atau gabungan beberapa unsur yang saling mendukung dan bekerja menurut prosedur tertentu untuk mencapai sasaran yang dituju.

\subsection{Definisi Informasi}

Istilah informasi sangat berbeda dengan data. Informasi adalah data yang telah diklasifikasikan atau diolah atau diinterpretasikan untuk digunakan dalam proses pengambilan keputusan. (Tata, 2012:24).

Menurut Gordon B. Navis, informasi adalah data yang telah diolah menjadi bentuk atau arti penting bagi si penerima serta memiliki nilai nyata dan dapat dirasakan dalam keputusan-keputusan saat ini atau yang akan datang. Sedangkan menurut Madden, informasi didefinisikan sebagai stimulus 
yang berasal dari satu sistem yang mempengaruhi interpretasi sistem lain dalam satu lingkungan. (Yakub dan Hisbanarto, 2014).

Menurut penjelasan di atas, informasi bisa diartikan sebagai data yang telah melalui proses pengolahan sedemikian rupa dan mempengaruhi kerja sistem untuk digunakan sebagai pendukung keputusan.

\subsection{Definisi Sistem Informasi}

Tata Sutabri menyatakan bahwa sistem informasi merupakan penerapan sistem di dalam organisasi untuk mendukung informasi yang dibutuhkan oleh semua tingkat manajemen. Sebelum adanya komputerisasi, sistem informasi menggunakan teknik penyaluran informasi melalui seorang manajer yang merencanakan dan mengendalikan operasinya. Sistem informasi yang terkomputerisasi menambahkan dimensi kecepatan, ketelitian, dan penyediaan data yang lebih besar yang memberikan bahan pertimbangan yang lebih luas untuk mengambil keputusan. Menurut Rainer (Yakub dan Hisbanarto, 2014), sistem informasi merupakan suatu kegiatan untuk mengumpulkan, memproses, menyimpan, menganalisis, dan menyebarkan informasi untuk tujuan tertentu.

Sistem informasi dapat disimpulkan sebagai kegiatan sistem yang mengolah dan menyalurkan informasi untuk tujuan pengambilan keputusan.

\subsection{Penilaian pada Kurikulum 2013}

Kurikulum 2013 meliputi Kompetensi Inti (KI) yaitu tingkat kemampuan untuk mencapai Standar Kompetensi Lulusan (SKL) yang harus dimiliki siswa. Kompetensi Inti terdiri atas:

1. Kompetensi Inti-1 (KI-1) untuk sikap spiritual;

2. Kompetensi Inti-2 (KI-2) untuk sikap sosial;

3. Kompetensi Inti-3 (KI-3) untuk pengetahuan; dan

4. Kompetensi Inti-4 (KI-4) untuk keterampilan. (Kemendikbud, 2017).

\section{Metodologi}

\subsection{Tempat dan Waktu Penelitian}

Penelitian dilakukan di sekolah sasaran, yaitu Sekolah Menengah Kejuruan Bakti Idhata, Cilandak, Jakarta Selatan sekitar selama bulan Maret 2018 hingga Agustus 2018.

\subsection{Metode Pengembangan Produk \\ 3.2.1 Tujuan Pengembangan}

Tujuan dari pengembangan sistem informasi akademik ini adalah mengembangkan kembali sistem penilaian akademik siswa pada SMK Bakti Idhata sebelumnya yang berupa aplikasi spreadsheet ke sistem informasi akademik berbasis web.

\subsubsection{Metode Pengembangan}

Metode pengembangan sistem ini menggunakan Research and Development dan metode pengembangan produknya, menerapkan Agile yaitu Scrum. Metode Scrum ini menggunakan gabungan iterasi dan incremental. Pengembangan dalam Scrum menggunakan sprint yang berulang atau iterasi dan menghasilkan incremental di akhir sprint. Dalam proses pengembangan, metode ini akan disesuaikan dengan peneliti yang tidak menggunakan tim pengembang.

\subsubsection{Sasaran Produk}

Produk ini direncanakan untuk diserahkan kepada pihak SMK Bakti Idhata. Adapun pihak yang disasari adalah wakil kepala sekolah bidang akademik, para guru mata pelajaran, dan siswa-siswi kelas X hingga XII baik jurusan Rekayasa Perangkat Lunak, Teknik Komputer Jaringan, maupun Multimedia.

\subsection{Prosedur Pengembangan}

Proses dalam Scrum menggunakan 3 fase, yaitu fase pre-game, fase pengembangan atau fase game, dan fase post-game. (Abrahamsson, et.al, 2002)

\subsubsection{Fase Pre-game}

Fase ini merupakan tahap perencanaan sistem yang akan dikembangkan. Perencanaan menggunakan daftar Product Backlog. Product Backlog mendefinisikan semua yang dibutuhkan dan yang dapat dikerjakan untuk mencapai produk akhir. Banyak pihak yang dapat berpartisipasi membuat daftar Product Backlog, seperti pelanggan, tim proyek, pemasaran, atau pengembang. Kebutuhan sistem dalam Product Backlog dibuat prioritas untuk implementasi. Di setiap iterasi, Product Backlog yang terbaru ditinjau kembali oleh tim Scrum untuk memantapkan komitmen tim atas iterasi selanjutnya. (Abrahamsson, et.al, 2002).

Peneliti akan membuat daftar Product Backlog dari sistem terdahulu yang berbasis spreadsheet. Setelah itu dilakukan prioritas sesuai dengan fungsionalnya dari fitur umum hingga fitur tambahannya.

\subsubsection{Fase Game}

Dalam fase game atau pengembangan, sistem dikembangkan melalui sprints. Desain sistem dikembangkan selama proses sprint. Satu sprint direncanakan dari satu pekan hingga satu bulan. Dalam sprint terdapat Planning Meetings, Sprint Backlog dan Daily Scrum Meetings. (Abrahamsson, et.al, 2002)

\subsubsection{Sprint Planning Meeting}

Dua fase pertemuan yang diatur oleh ketua tim Scrum sebelum memulai sprint. Pelanggan, pengguna, manajemen, pemilik produk dan tim Scrum berpartisipasi dalam pertemuan fase pertama 
untuk memutuskan tujuan dan fungsionalitas pada sprint yang akan datang. Pertemuan fase kedua dilakukan oleh ketua dan tim Scrum untuk membahas incremental produk yang digunakan selama sprint.

Peneliti akan menggunakan fase pertama pada pertemuan awal dengan pelanggan dalam hal ini Kepala Program Studi SMK Bakti Idhata untuk menentukan kebutuhan sistem dari Product Backlog serta membaginya ke Sprint Backlog.

\subsubsection{Sprint Backlog}

Sprint Backlog adalah tahap pertama di setiap sprint. Berisi daftar Product Backlog yang dipilih untuk menjalankan sprint. Daftar Sprint Backlog ini hasil dari Sprint Planning Meeting yang dilakukan tim Scrum sesuai dengan daftar prioritasnya.. Daftar Sprint Backlog akan selalu sama sampai sprint berakhir.

Peneliti akan menggunakan Sprint Backlog yang telah disepakati dengan pihak sekolah untuk digunakan dalam proses pengembangan sistem menggunakan sprint.

\subsubsection{Daily Scrum Meeting}

Daily Scrum Meeting berguna dalam mengatur dan membahas perkembangan sprint agar selalu dalam jalurnya. Biasanya pertemuan dilakukan 15 menit setiap hari. Pertemuan ini tidak dilakukan peneliti karena pertemuan harian ini berlaku untuk tim Scrum.

\subsubsection{Sprint Review Meeting}

Pada akhir dari sebuah sprint, tim Scrum menunjukkan hasil sprint berupa produk incremental kepada manajemen, pelanggan, pengguna atau pemilik produk pada sebuah pertemuan informal untuk ditinjau. Hasil peninjauan menghasilkan daftar Backlog baru. Pihak sekolah akan mengulas hasil sprint untuk memastikan Sprint Backlog sesuai dengan rencana.

\subsubsection{Fase Post-game}

Fase terakhir untuk perilisan sistem saat kebutuhan sistem telah lengkap dan disepakati. Memasuki fase ini sudah tidak ada masalah dan hal yang akan ditambahkan karena sudah dilakukan testing sistem. (Abrahamsson, et.al, 2002).

Pengujian sistem akan dilakukan di SMK Bakti Idhata yang dilakukan oleh pihak yang terkait dengan sistem.

\subsection{Teknik Pengumpulan Data}

Peneliti dalam mengumpulkan data menggunakan teknik sebagai berikut :

1. Kuesioner. Pengambilan data secara tertulis dengan menyediakan pertanyaan kepada responden dari pihak sekolah yaitu Kepala Program Studi dan Guru di SMK Bakti Idhata. Kuesioner terkait fungsional dan fitur yang akan diimplementasikan ke sistem baru dan masih terkait dengan aplikasi sebelumnya.

2. Studi Dokumen. Peneliti akan mengumpulkan data dan mempelajari dokumen terkait sistem, yaitu data guru, mata pelajaran, dan siswa di SMK Bakti Idhata.

\subsection{Teknik Analisis Data}

Peneliti akan menggunakan analisis produk menggunakan Black-box testing atau behavioral testing. Pengujian ini berfokus pada kebutuhan fungsional dari sistem. Jadi pengujian akan berhasil jika fungsi-fungsi yang diuji berjalan sesuai harapan dan rencana.

Black-box testing bertujuan untuk menemukan kesalahan pada fungsi sistem, tampilan, struktur data, akses basis data, performa, dan penanganan kesalahan. (Pressman, 2010)

\section{Hasil dan Pembahasan \\ 4.1 Hasil Pengembangan Produk}

Pengembangan sistem dalam penelitian ini menggunakan metode scrum yang terdiri dari tiga fase, yaitu fase pre-game, fase game, dan fase postgame. Segala perencanaan sebelum memulai proses pengembangan sistem dilakukan pada fase pre-game seperti penentuan product backlog, task list dan jadwal pengerjaan sistemnya. Pada fase game dilakukan pengembangan produk secara iterasi mulai dari perancangan, desain, membuat kode dan pengujian sistem sesuai jumlah sprint. Di fase postgame produk sudah dapat dikatakan selesai dikembangkan. Terdapat empat pengguna yang terlibat dalam penggunaan sistem informasi akademik ini, yaitu administrator, guru mata pelajaran, wali kelas, dan siswa.

\subsubsection{Fase Pre-game}

Hasil pengembangan produk ini akan menghasilkan fitur-fitur yang direncanakan dalam bentuk sprint backlog. Sprint backlog ini membutuhkan persetujuan pihak sekolah selaku klien. Kesepakatan sprint backlog yang akan digunakan dalam proses pengembangan produk diraih melalui sprint planning meeting dengan menyebarkan kuesioner kepada klien, hasil kesepakatan sprint backlog yang dipakai yang terbagi dalam dua sprint disajikan dalam tabel 4.1. Dalam sprint akan dilakukan proses pengembangan dengan melakukan perancangan, desain, melakukan kode program, lalu sampai akhirnya dilakukan pengujian 
Tabel 4.1 Sprint Backlog yang Disepakati

\begin{tabular}{|c|c|c|}
\hline & No. & Product Backlog \\
\hline \multirow{8}{*}{$\frac{\bar{a}}{\frac{2}{2}}$} & 1 & Administrator dapat login dan logout \\
\hline & 2. & $\begin{array}{l}\text { Administrator dapat memasukkan data } \\
\text { sekolah seperti guru, wali kelas, siswa, } \\
\text { kelas, pelajaran, dan ekskul }\end{array}$ \\
\hline & 3. & $\begin{array}{l}\text { Administrator dapat membuat akun guru, } \\
\text { wali kelas, dan siswa }\end{array}$ \\
\hline & 4. & Guru mata pelajaran dapat login dan logout \\
\hline & 5. & Wali kelas dapat login dan logout \\
\hline & 6. & Siswa dapat login dan logout \\
\hline & 7. & $\begin{array}{l}\text { Guru mata pelajaran dapat memasukkan } \\
\text { data penilaian akademik seperti nilai tugas, } \\
\text { ulangan, UTS, dan UAS serta sikap dan } \\
\text { spiritual }\end{array}$ \\
\hline & 8. & $\begin{array}{l}\text { Wali kelas dapat memasukkan data } \\
\text { penilaian non akademik seperti nilai } \\
\text { prakerin, ekskul, prestasi, dan kehadiran }\end{array}$ \\
\hline \multirow{6}{*}{ 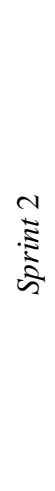 } & 9. & $\begin{array}{l}\text { Administrator dapat melihat seluruh data } \\
\text { sekolah dan data penilaian siswa }\end{array}$ \\
\hline & 10. & Siswa dapat melihat data penilaian dirinya \\
\hline & 11. & $\begin{array}{l}\text { Guru mata pelajaran dapat melihat laporan } \\
\text { nilai siswa yang mengambil mata } \\
\text { pelajarannya }\end{array}$ \\
\hline & 12. & $\begin{array}{l}\text { Wali kelas dapat melihat laporan nilai siswa } \\
\text { kelas yang dibimbingnya }\end{array}$ \\
\hline & 13. & $\begin{array}{l}\text { Wali kelas dapat mencetak laporan nilai } \\
\text { berupa leger dan rapor }\end{array}$ \\
\hline & 14 & $\begin{array}{l}\text { Wali kelas dapat melihat laporan kenaikan } \\
\text { kelas siswa yang dibimbingnya berdasarkan } \\
\text { penilaian }\end{array}$ \\
\hline
\end{tabular}

Setiap sprint backlog dijalankan dengan mengerjakan setiap product backlog yang telah ditentukan. Pada penelitian ini dilakukan sprint sebanyak dua kali dengan estimasi waktu setiap sprint selama satu bulan. Dalam setiap product backlog akan dirinci lagi menjadi task list yang menjadi daftar pekerjaan yang harus dilakukan dalam proses pengembangan sistem.

Pada sprint pertama kebutuhan sistem yang ditekankan adalah akses pengguna ke sistem dan pemasukan data-data yang dilakukan oleh administrator, guru, dan wali kelas baik data sekolah maupun data penilaian. Daftar pekerjaan dan estimasi waktu yang dilakukan selama sprint pertama disajikan dalam tabel 4.2 dan 4.3.

Tabel 4.2 Product Backlog Sprint Pertama

\begin{tabular}{|c|l|l|c|}
\hline No. & \multicolumn{1}{|c|}{$\begin{array}{c}\text { Product } \\
\text { Backlog }\end{array}$} & \multicolumn{1}{|c|}{ Task List } & $\begin{array}{c}\text { Esti- } \\
\text { masi }\end{array}$ \\
\hline \multirow{2}{*}{1.} & \multirow{2}{*}{$\begin{array}{l}\text { Administrator } \\
\text { dapat login } \\
\text { dan logout }\end{array}$} & $\begin{array}{l}\text { Membuat desain interface } \\
\text { login administrator }\end{array}$ & $\begin{array}{l}\text { Membuat desain } \text { interface } \\
\text { halaman administrator }\end{array}$ \\
\cline { 3 - 4 } & $\begin{array}{l}\text { Membuat kode login } \\
\text { administrator }\end{array}$ & 1 jam \\
\cline { 3 - 4 } & $\begin{array}{l}\text { Membuat kode halaman } \\
\text { administrator }\end{array}$ & 2 jam \\
\hline 2. & $\begin{array}{l}\text { Administrator } \\
\text { dapat }\end{array}$ & $\begin{array}{l}\text { Membuat desain interface } \\
\text { halaman data kelas }\end{array}$ & 1 jam \\
\hline
\end{tabular}

\begin{tabular}{|c|c|c|c|}
\hline & \multirow{11}{*}{$\begin{array}{l}\text { memasukkan } \\
\text { data sekolah } \\
\text { seperti guru, } \\
\text { wali kelas, } \\
\text { siswa, kelas, } \\
\text { pelajaran, dan } \\
\text { ekskul }\end{array}$} & $\begin{array}{l}\text { Membuat desain interface } \\
\text { halaman data guru }\end{array}$ & $1 \mathrm{jam}$ \\
\hline & & $\begin{array}{l}\text { Membuat desain interface } \\
\text { halaman data pelajaran }\end{array}$ & 1 jam \\
\hline & & $\begin{array}{l}\text { Membuat desain interface } \\
\text { halaman data wali kelas }\end{array}$ & 1 jam \\
\hline & & $\begin{array}{l}\text { Membuat desain interface } \\
\text { halaman data siswa }\end{array}$ & 1 jam \\
\hline & & $\begin{array}{l}\text { Membuat desain interface } \\
\text { halaman data ekskul }\end{array}$ & 1 jam \\
\hline & & $\begin{array}{l}\text { Membuat kode halaman data } \\
\text { kelas }\end{array}$ & 2 jam \\
\hline & & $\begin{array}{l}\text { Membuat kode halaman data } \\
\text { guru }\end{array}$ & 3 jam \\
\hline & & $\begin{array}{l}\text { Membuat kode halaman data } \\
\text { pelajaran }\end{array}$ & 2 jam \\
\hline & & $\begin{array}{l}\text { Membuat kode halaman data } \\
\text { wali kelas }\end{array}$ & $3 \mathrm{jam}$ \\
\hline & & $\begin{array}{l}\text { Membuat kode halaman data } \\
\text { siswa }\end{array}$ & 3 jam \\
\hline & & $\begin{array}{l}\text { Membuat kode halaman data } \\
\text { ekskul }\end{array}$ & 1 jam \\
\hline \multirow{6}{*}{3.} & \multirow{6}{*}{$\begin{array}{l}\text { Administrator } \\
\text { dapat } \\
\text { membuat } \\
\text { akun guru, } \\
\text { wali kelas, } \\
\text { dan siswa }\end{array}$} & $\begin{array}{l}\text { Membuat desain interface } \\
\text { halaman akun guru }\end{array}$ & $1 \mathrm{jam}$ \\
\hline & & $\begin{array}{l}\text { Membuat desain interface } \\
\text { halaman akun wali kelas }\end{array}$ & 1 jam \\
\hline & & $\begin{array}{l}\text { Membuat desain interface } \\
\text { halaman akun siswa }\end{array}$ & 1 jam \\
\hline & & $\begin{array}{l}\text { Membuat kode halaman akun } \\
\text { guru }\end{array}$ & 2 jam \\
\hline & & $\begin{array}{l}\text { Membuat kode halaman akun } \\
\text { wali kelas }\end{array}$ & 2 jam \\
\hline & & $\begin{array}{l}\text { Membuat kode halaman akun } \\
\text { siswa }\end{array}$ & 2 jam \\
\hline \multirow{4}{*}{4.} & \multirow{4}{*}{$\begin{array}{l}\text { Guru mata } \\
\text { pelajaran } \\
\text { dapat login } \\
\text { dan logout }\end{array}$} & $\begin{array}{l}\text { Membuat desain interface } \\
\text { login guru mata pelajaran }\end{array}$ & $1 \mathrm{jam}$ \\
\hline & & $\begin{array}{l}\text { Membuat desain interface } \\
\text { halaman guru mata pelajaran }\end{array}$ & 1 jam \\
\hline & & $\begin{array}{l}\text { Membuat kode login guru } \\
\text { mata pelajaran }\end{array}$ & $3 \mathrm{jam}$ \\
\hline & & $\begin{array}{l}\text { Membuat kode halaman guru } \\
\text { mata pelajaran }\end{array}$ & 3 jam \\
\hline \multirow{4}{*}{5.} & \multirow{4}{*}{$\begin{array}{l}\text { Wali kelas } \\
\text { dapat login } \\
\text { dan logout }\end{array}$} & $\begin{array}{l}\text { Membuat desain interface } \\
\text { login wali kelas }\end{array}$ & $1 \mathrm{jam}$ \\
\hline & & $\begin{array}{l}\text { Membuat desain interface } \\
\text { halaman wali kelas }\end{array}$ & 1 jam \\
\hline & & $\begin{array}{l}\text { Membuat kode login wali } \\
\text { kelas }\end{array}$ & $2 \mathrm{jam}$ \\
\hline & & $\begin{array}{l}\text { Membuat kode halaman wali } \\
\text { kelas }\end{array}$ & $3 \mathrm{jam}$ \\
\hline \multirow{4}{*}{6.} & \multirow{4}{*}{$\begin{array}{l}\text { Siswa dapat } \\
\text { login dan } \\
\text { logout }\end{array}$} & $\begin{array}{l}\text { Membuat desain interface } \\
\text { login siswa }\end{array}$ & $1 \mathrm{jam}$ \\
\hline & & $\begin{array}{l}\text { Membuat desain interface } \\
\text { halaman siswa }\end{array}$ & $1 \mathrm{jam}$ \\
\hline & & Membuat kode login siswa & $2 \mathrm{jam}$ \\
\hline & & $\begin{array}{l}\text { Membuat kode halaman } \\
\text { siswa }\end{array}$ & $3 \mathrm{jam}$ \\
\hline \multirow{4}{*}{7.} & \multirow{4}{*}{$\begin{array}{l}\text { Guru mata } \\
\text { pelajaran } \\
\text { dapat } \\
\text { memasukkan } \\
\text { data penilaian } \\
\text { akademik } \\
\text { seperti nilai } \\
\text { tugas, } \\
\text { ulangan, } \\
\text { UTS, dan } \\
\text { UAS serta } \\
\text { sikap dan } \\
\text { spiritual }\end{array}$} & $\begin{array}{l}\text { Membuat desain interface } \\
\text { halaman daftar siswa dan } \\
\text { kelas yang dibimbing }\end{array}$ & $2 \mathrm{jam}$ \\
\hline & & $\begin{array}{l}\text { Membuat desain interface } \\
\text { halaman edit nilai akademik } \\
\text { siswa }\end{array}$ & 2 jam \\
\hline & & $\begin{array}{l}\text { Membuat kode halaman } \\
\text { daftar siswa dan kelas yang } \\
\text { dibimbing }\end{array}$ & $3 \mathrm{jam}$ \\
\hline & & $\begin{array}{l}\text { Membuat kode halaman edit } \\
\text { nilai akademik siswa }\end{array}$ & 4 jam \\
\hline 8. & $\begin{array}{l}\text { Wali kelas } \\
\text { dapat } \\
\text { memasukkan }\end{array}$ & $\begin{array}{l}\text { Membuat desain interface } \\
\text { halaman daftar siswa } \\
\text { dibimbing wali kelas }\end{array}$ & 2 jam \\
\hline
\end{tabular}




\begin{tabular}{|l|l|l|c|}
\hline \multirow{2}{*}{$\begin{array}{l}\text { data penilaian } \\
\text { non akademik } \\
\text { seperti nilai } \\
\text { prakerin, } \\
\text { ekskul, } \\
\text { prestasi, dan } \\
\text { kehadiran }\end{array}$} & $\begin{array}{l}\text { Membuat desain interface } \\
\text { halaman edit nilai non } \\
\text { akademik siswa }\end{array}$ & $\begin{array}{l}\text { 2 jam } \\
\text { Membuat kode halaman } \\
\text { daftar siswa dibimbing wali } \\
\text { kelas }\end{array}$ & 4 jam \\
\cline { 2 - 3 } & $\begin{array}{l}\text { Membuat kode halaman edit } \\
\text { nilai non akademik siswa }\end{array}$ & 4 jam \\
\hline \multicolumn{2}{|c}{ Total } & $\mathbf{8 0}$ jam \\
\hline
\end{tabular}

Tabel 4.3 Waktu Kerja Sprint Pertama

\begin{tabular}{|l|l|}
\hline Total Estimasi & $80 \mathrm{Jam}$ \\
\hline Lama Sprint & 4 Minggu \\
\hline Total Hari Kerja & $20 \mathrm{Hari}$ \\
\hline Jumlah Jam per Hari Kerja & 4 Jam per Hari Kerja \\
\hline
\end{tabular}

Sedangkan pada sprint kedua kebutuhan sistem yang ditekankan adalah menampilkan data dan hasil laporan. Daftar pekerjaan dan estimasi waktu yang dilakukan selama sprint kedua disajikan dalam tabel 4.4 dan 4.5.

Tabel 4.4 Product Backlog Sprint Kedua

\begin{tabular}{|c|c|c|c|}
\hline No. & Product Backlog & Task List & $\begin{array}{l}\text { Esti- } \\
\text { masi }\end{array}$ \\
\hline \multirow[t]{2}{*}{1.} & \multirow{2}{*}{$\begin{array}{l}\text { Administrator } \\
\text { dapat melihat } \\
\text { seluruh data } \\
\text { sekolah dan data } \\
\text { penilaian siswa }\end{array}$} & $\begin{array}{l}\text { Membuat desain } \\
\text { interface halaman data } \\
\text { penilaian siswa }\end{array}$ & 1 jam \\
\hline & & $\begin{array}{l}\text { Membuat kode halaman } \\
\text { data penilaian siswa }\end{array}$ & 3 jam \\
\hline \multirow[t]{2}{*}{2.} & \multirow{2}{*}{$\begin{array}{l}\text { Siswa dapat } \\
\text { melihat data } \\
\text { penilaian dirinya }\end{array}$} & $\begin{array}{l}\text { Membuat desain } \\
\text { interface halaman data } \\
\text { penilaian siswa }\end{array}$ & 1 jam \\
\hline & & $\begin{array}{l}\text { Membuat kode halaman } \\
\text { data penilaian siswa }\end{array}$ & 3 jam \\
\hline \multirow{2}{*}{3.} & \multirow{2}{*}{$\begin{array}{l}\text { Guru mata } \\
\text { pelajaran dapat } \\
\text { melihat laporan } \\
\text { nilai siswa yang } \\
\text { mengambil mata } \\
\text { pelajarannya }\end{array}$} & $\begin{array}{l}\text { Membuat desain } \\
\text { interface } \text { halaman } \\
\text { laporan penilaian siswa }\end{array}$ & 1 jam \\
\hline & & $\begin{array}{l}\text { Membuat kode halaman } \\
\text { laporan penilaian siswa }\end{array}$ & 5 jam \\
\hline \multirow[t]{2}{*}{4.} & \multirow{2}{*}{$\begin{array}{l}\text { Wali kelas dapat } \\
\text { melihat laporan } \\
\text { nilai siswa kelas } \\
\text { yang } \\
\text { dibimbingnya }\end{array}$} & $\begin{array}{l}\text { Membuat desain } \\
\text { interface } \text { halaman } \\
\text { laporan penilaian siswa }\end{array}$ & $1 \mathrm{jam}$ \\
\hline & & $\begin{array}{l}\text { Membuat kode halaman } \\
\text { laporan penilaian siswa }\end{array}$ & 5 jam \\
\hline \multirow[t]{2}{*}{5.} & \multirow{2}{*}{$\begin{array}{l}\text { Wali kelas dapat } \\
\text { mencetak laporan } \\
\text { nilai berupa leger } \\
\text { dan rapor }\end{array}$} & $\begin{array}{l}\text { Membuat desain } \\
\text { interface halaman } \\
\text { laporan nilai berupa } \\
\text { leger dan rapor }\end{array}$ & 2 jam \\
\hline & & $\begin{array}{l}\text { Membuat kode halaman } \\
\text { laporan nilai berupa } \\
\text { leger dan rapor }\end{array}$ & 8 jam \\
\hline \multirow[t]{2}{*}{6.} & \multirow{2}{*}{$\begin{array}{l}\text { Wali kelas dapat } \\
\text { melihat laporan } \\
\text { kenaikan kelas } \\
\text { siswa yang } \\
\text { dibimbingnya } \\
\text { berdasarkan } \\
\text { penilaian }\end{array}$} & $\begin{array}{l}\text { Membuat desain } \\
\text { interface halaman } \\
\text { laporan kenaikan kelas } \\
\text { siswa }\end{array}$ & 2 jam \\
\hline & & $\begin{array}{l}\text { Membuat kode halaman } \\
\text { laporan kenaikan kelas } \\
\text { siswa }\end{array}$ & 8 jam \\
\hline \multicolumn{3}{|c|}{ Total } & 40 jam \\
\hline
\end{tabular}

Tabel 4.5 Waktu Kerja Sprint Kedua

\begin{tabular}{|l|l|}
\hline Total Estimasi & 40 Jam \\
\hline Lama Sprint & 4 Minggu \\
\hline Total Hari Kerja & 20 Hari \\
\hline Jumlah Jam per Hari Kerja & 2 Jam per Hari Kerja \\
\hline
\end{tabular}

\subsubsection{Fase Game}

\subsubsection{Rancangan Basis Data}

Data yang digunakan dalam pengembangan sistem informasi akademik ini dapat terbagi menjadi dua bagian, yaitu data-data sekolah seperti data guru, siswa, kelas dan data-data penilaian seperti data nilai, kehadiran, prestasi, dan ekskul.

\subsubsection{Desain Antar Muka}

Membuat desain antar muka diperlukan sebelum membuat kode program untuk memberikan gambaran dan fitur yang akan disajikan di sistem ini. Desain sistem meliputi empat pengguna, yaitu administrator, guru, wali kelas, dan siswa. Pada administrator terdapat menu data sekolah dan data penilaian. Pada guru terdapat menu data daftar kelas yang dibimbingnya. Pada wali kelas terdapat menu data kelasnya dan laporan nilai. Sedangkan pada siswa terdapat menu data penilaiannya.

\subsubsection{Implementasi Sprint}

Setelah dilakukan perancangan dan desain, pengerjaan kode program dilakukan sesuai jadwal yang telah ditentukan untuk menjaga komitmen terhadap waktu. Sesuai rancangan pada tahap pregame, kode program dilakukan setelah dilakukan desain interface di setiap product backlog.

\subsubsection{Sprint Review Meeting}

Di akhir sprint dilakukan peninjauan untuk mengulas sprint agar sesuai dengan rancangan sprint backlog. Kegiatan mengulas berupa menguji sistem dengan mencocokkan product backlog dengan hasil uji fungsi sistem. Pengujian sistem dilakukan sejumlah sprint yang dilakukan, yaitu dua kali dengan menggunakan lembar kuesioner.

\subsubsection{Fase Post-Game}

Fase ini kebutuhan sistem telah lengkap dan disepakati oleh klien.

\subsection{Pembahasan \\ 4.2.1 Pembahasan Tampilan}

Tampilan pada sistem informasi akademik ini rata-rata memiliki kesamaan, yaitu memiliki tampilan menu di sebelah kiri dan di tengah tampilan utamanya berada. Perbedaan mendasarnya adalah pada fungsi yang disajikan berdasarkan jenis hak akses pengguna. Pengguna sistem ini terbagi menjadi empat jenis, yaitu administrator, guru mata pelajaran, wali kelas, dan siswa.

Pada tampilan pengguna administrator, seluruh akses data dapat dilakukan oleh pengguna ini, sehingga tampilannya terdiri atas menu data sekolah dan data penilaian. Pada tampilan data sekolah terdiri atas kelas, guru, mata pelajaran, wali kelas, siswa, dan ekskul dengan tampilan utamanya berupa tabel yang datanya dapat ditambah, diedit, maupun dihapus. Berbeda dengan data sekolah, pada data penilaian administrator hanya dapat melihat datanya saja tanpa 
akses mengubah data, hal ini dikarenakan pengubahan penilaian khusus dilakukan oleh guru mata pelajaran dan wali kelas.

Tampilan pengguna guru lebih fokus kepada tampilan per kelas yang dibimbingnya. Kelas yang tidak dibimbing oleh guru tertentu tidak akan ditampilkan. Di setiap kelas yang dipilih terdapat tampilan untuk mengubah bobot penilaian dan jumlah tugas dan ulangan harian yang dilakukan karena kondisi penilaian kelas yang mungkin berbeda. Tampilan utama berupa tabel ringkasan penilaian siswa dengan setiap barisnya dapat dilihat detail lengkap penilaiannya. Halaman detail penilaian siswa memiliki dua fungsi, yaitu sebagai halaman pratinjau detail penilaian dan sebagai halaman pemasukan atau pengubahan data penilaian. Guru juga dapat langsung mengunduh tabel penilaian per kelas di tampilan utama.

Tampilan pengguna wali kelas hampir sama dengan tampilan pada guru mata pelajaran karena peran yang serupa dalam menangani penilaian siswa. Kelas yang ditangani tentu hanya satu. Penilaian yang ditangani wali kelas adalah penilaian di luar akademis, seperti nilai ekskul, jumlah kehadiran, prestasi, dan prakerin atau praktik kerja industri. Khusus pada semester genap, terdapat kolom keputusan kenaikan kelas pada tabel daftar siswa. Kolom ini terhubung dengan halaman detail keputusan kenaikan kelas. Keputusan kenaikan kelas didasari oleh 5 faktor, yaitu nilai akhir per mata pelajaran, kehadiran, nilai ekskul, jumlah prestasi (bila ada) dan nilai prakerin (khusus kelas XI ke atas). Faktor-faktor tersebut adalah hasil pertimbangan yang diminta klien saat mengumpulkan data (disajikan pada lampiran 48). Masing-masing faktor akan mendukung kenaikan kelas apabila nilai akademik sesuai atau melebihi kriteria kelulusan minimal (KKM) yang ditetapkan atau dengan predikat nilai minimal baik (nilai 70). Siswa dapat dikatakan naik kelas jika minimal 50\% dari jumlah faktor memenuhi kriteria. Kolom keputusan kenaikan kelas ini hanya sebagai pendukung keputusan wali kelas dalam menaikkan kelas siswa, keputusan sesungguhnya adalah dari hasil kesepakatan pihak sekolah yang telah didiskusikan.

Menu tambahan pada pengguna wali kelas adalah tampilan laporan, baik laporan leger (laporan penilaian per semester per kelas) maupun laporan rapor (laporan nilai per siswa). Sebelum wali kelas dapat mengunduh laporan, akan disajikan pratinjau terlebih dahulu untuk memberikan gambaran laporan sebelum diunduh.

Tampilan pengguna siswa lebih sederhana dengan hak akses hanya untuk melihat hasil penilaian. Hasil penilaian yang dapat dilihat siswa terdiri atas penilaian akademik yang dikelompokkan berdasarkan mata pelajaran dan penilaian non akademik yang terdiri atas kehadiran, ekskul, prestasi dan prakerin. Penilaian akademik yang ditampilkan hanya berupa nilai tugas, ulangan harian, ulangan tengah semester (UTS) dan ulangan akhir semester (UAS). Nilai yang tidak memenuhi kriteria kelulusan minimal (KKM) akan ditampilkan dengan warna yang berbeda agar siswa dapat mudah mengetahui nilai yang perlu diperbaiki.

\subsubsection{Pembahasan Hasil Pengujian Fungsional / Black Box Testing}

Pengujian fungsional dilakukan setiap setelah melaksanakan sprint, jadi sebanyak dua kali. Responden berasal dari warga SMK Bakti Idhata Jakarta pada sprint pertama dan kedua dengan rincian pengguna yaitu administrator, guru mata pelajaran, wali kelas, dan siswa.

Pada pengujian pertama, hampir keseluruhan fungsi dapat berjalan dengan baik kecuali dua fungsi yang masih perlu diperbaiki, yaitu fungsi halaman daftar data nilai per kelas dan detail nilai siswa. Fungsi tersebut akan diperbaiki pada sprint selanjutnya yaitu pada sprint kedua, fungsi dari fitur yang dikerjakan di sprint kedua akan di uji di pengujian kedua. Di pengujian kedua seluruh fungsi dapat berjalan dengan semestinya tanpa adanya hambatan, fungsi yang di pengujian sebelumnya di sprint pertama yang belum sempurna sudah diperbaiki seutuhnya. Kedua pengujian ini hasilnya dapat dikatakan bahwa sistem informasi dapat berjalan dengan baik dan secara fungsional sudah sesuai dengan daftar product backlog yang direncanakan dan disepakati.

\section{Kesimpulan dan Saran}

Berdasarkan pembahasan kegiatan pengembangan sistem informasi akademik berbasis web di SMK Bakti Idhata Jakarta, maka dapat diambil kesimpulan bahwa penelitian ini menghasilkan sistem informasi akademik berbasis web. Pengembangan sistem ini menggunakan metode scrum dengan tahapan mulai dari perancangan pada tahap pre-game, proses pengerjaan sistem pada tahap game, hingga sistem selesai pada post-game.

Berdasarkan hasil pengujian fungsional, sistem yang dikembangkan sudah dapat digunakan karena telah memenuhi seluruh kebutuhan yang diminta pihak pengguna (sekolah).

Metode pengembangan yang diterapkan pada penelitian ini cocok digunakan untuk pengembangan sistem yang memiliki kebutuhan yang dinamis lambat, tim dengan jumlah anggota lebih kecil dan pengerjaan waktu yang terstruktur serta relatif singkat

Penulis memiliki saran untuk pengembangan selanjutnya atau penelitian yang sejenis, yaitu perlunya pengembangan lebih lanjut dari aspek keamanan sistem (security system). Basis data yang digunakan di sistem ini cukup besar, perlu dibuat efisiensi dalam hal pemasukan data.

Mengembangkan fungsi keputusan kenaikan kelas dengan menerapkan metode sistem pengambilan keputusan yang lebih lanjut. 
Integrasi dengan sistem lain yang memiliki data terkait, seperti sistem kehadiran siswa.

Dalam implementasi sistem informasi ini, diperlukan minimal server dengan ruang penyimpanan sebanyak $1 \mathrm{~GB}$, php versi 5.6, database MySQL, dan browser client di sistem operasi Windows, MacOS, dan Linux dengan dukungan HTML versi 5 dan javascript.

\section{Daftar Pustaka:}

Abrahamsson, P., Salo, O., Ronkainen, J., \& Warsta, J. (2002), Agile Software Development Methods: Review and Analysis, VTT PUBLICATIONS 478, pp. 18-88.

Anggadini, Sri Dewi. (2013), Analisis Sistem Informasi Manajemen Berbasis Komputer dalam Proses Pengambilan Keputusan, Bandung, Majalah Ilmiah UNIKOM, Vol. 11 No.2, pp. 176-187.

Arti, Shindy. (2016), Sistem Manajemen Proposal Tugas Akhir Berbasis Web pada Program Studi Pendidikan Teknik Informatika dan Komputer Universitas Negeri Jakarta, Jakarta, Universitas Negeri Jakarta, pp. 49-75.

Kementerian Pendidikan dan Kebudayaan, Direktorat Jenderal Pendidikan Dasar dan Menengah, Direktorat Pembinaan Sekolah Menengah Kejuruan. (2017), Panduan Penilaian Hasil Belajar pada Sekolah Menengah Kejuruan, Jakarta, Kemendikbud, pp. 8-34.

Krisnanda, Made. (2014), Implementasi Metodologi SCRUM dalam Pembangunan Situs Harga Komoditas, Universitas Katolik De La Salle, Manado, Jurnal Sistem Informasi, Vol. 9 No. 2, pp. 149-160.

Lutfianto, Muhammad Andi. (2015), Pengembangan Sistem Latihan Ujian Nasional (Try Out) pada SMA Islam Jepara dengan Menggunakan Pendekatan Metode Scrum. Semarang, Universitas Dian Nuswantoro, pp. 35-93.

Mahirah, B. (2017), Evaluasi Belajar Peserta Didik (Siswa), UIN Alauddin Makassar, Jurnal Idaarah, Vol. I No. 2, pp. 257-267.

Nugroho, Bunafit. (2014), Pemrograman Web: Membuat Sistem Informasi Akademik Sekolah dengan PHP mysql dreamweaver (cet. 1), Yogyakarta, Gava Media, pp.

Pressman R. S. (2010), Software Engineering: A Practitioner's Approach, Mc Grow Hill, Ed ke7.

Rivai, Dani Ainur, \& Purnama, Bambang Eka. (2014), Pembangunan Sistem Informasi Pengolahan Data Nilai Siswa Berbasis Web pada Sekolah Menengah Kejuruan (SMK) Miftahul Huda Ngadirojo, Indonesian Journal on Networking and Security, Vol. 3 No. 2, pp. 19-25.
Sutabri, T. (2012), Analisis Sistem Informasi, Yogyakarta, Penerbit Andi.

Wibawa, Julian Chandra. (2013), Implementasi Sistem Informasi Akademik Studi Kasus SMP Negeri 20 Bandung, Bandung, Universitas Komputer Indonesia, pp. 3-9.

Wibowo, Arie Satryo. (2015), Kelebihan dan Kekurangan Sistem Informasi pada Perusahaan, Bogor, Institut Pertanian Bogor, pp. 8-12.

Yakub, \& Hisbanarto, V. (2014), Sistem Informasi Manajemen Pendidikan, Yogyakarta, Graha Ilmu. 